\title{
Professor Anatol Dowżenko - clinical neurologist, scientist and educator
}

\author{
Jerzy Kulczycki, Maria Barańska-Gieruszzzak
}

Institute of Psychiatry and Neurology in Warsaw

Professor Anatol Dowżenko was without doubt one of Poland's most prominent neurologists of the $20^{\text {th }}$ century. He was born in Russia, in Sergievskie Mineralnye Vody, on 2 July 1905 . He was the son of a lawyer, Tymoteusz Dowżenko. After completing secondary education in Lutsk, Dowżenko enrolled at the Poznan University, initially at the Faculty of Mathematics and Natural Sciences. After a year, however, he transferred to the Univer-

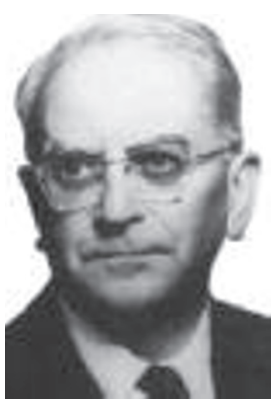

partment in 1950, soon earned a reputation as an outstanding scholar and educator. In recognition of his merits, he held the position of Vice-Rector in 1953-1955 and was elected Rector in 1956. It was also at that time that he achieved the full professorial title. During his work in Poznań, Prof. Dowżenko was a Member of the Qualification Committee for Science Staff.

In addition to pursuing his interest in ceresity's Faculty of Medicine. He graduated in 1932, earning the title of Doctor of General Medicine (Doctor Medicinae Universae). Between 1932 and 1939, Dowżenko worked as an assistant at the Neurology Department in Poznań under Prof. Borowiecki and then Prof. Zieliń ski. One of Dowżenko's first publications (co-authored with Prof. Borowiecki) about malaria treatment of central nervous system syphilis dates from that period. The beginning of WWII found the young doctor in Warsaw, where he continued working as a senior assistant at the Neurology Department under the supervision of Prof. Orzechowski and later Prof. Opalski. He was actively involved in the underground movement and held classes with students of the underground Medical Faculty.

After the end of the war Dowżenko further pursued his scientific career. In 1947-1948, he made a scientific journey to the USA, Canada and England, and in 1949 he was awarded his habilitation from the University of Warsaw for his thesis on Odma czaszkowa jako czynnik drazniacy mózgowe ośrodki regulacji krwi i jej wptyw na stan morfologiczny szpiku i krwi obwodowej [Cranial oedema as a factor irritating brain centres for blood regulation and its impact on the morphological status of bone marrow and peripheral blood]. Shortly after earning his habilitation, Dowżenko was granted the academic title of Professor Extraordinarius (Associate Professor) and appointed as Head of the Neurology Department of the Poznań University (which was soon to become the University of Medical Sciences). Professor Dowżenko, who took over as Head of the De- brospinal fluid (CSF), syphilis of the nervous system and extrapyramidal system diseases, in his Department Prof. Dowżenko initiated studies into multiple sclerosis and other demyelinating processes, contributing to the establishment of a team of scientists who investigated these areas for many years to come (the so-called "Poznan School”). It was also in Poznań that Dowżenko started his research into epilepsy.

In 1962, Dowżenko returned to Warsaw to take over as Head of the Neurology Department at the Psycho neurology Institute which was based in Pruszków until 1973 and was later relocated to Warsaw, changing name into the Institute of Psychiatry and Neurology. Professor Dowżenko held the position until the end of 1975, when he retired, remaining the Department's consultant for several months. He died suddenly on 20 April 1976, barely several weeks after celebrations marking the $45^{\text {th }}$ anniversary of his professional career.

Professor Anatol Dowżenko was a neurologist by heart. From the very beginning of his professional career, through effort and hard work, Dowżenko sought to gain insights into a variety of neurological topics. He eventually became a brilliant, precise and empathetic clinicist, and a universally recognized expert in this area of medicine. In his pursuit of knowledge he frequently encountered problems that required explanation and resolution. They spurred him on to continue his creative scientific endeavors. The main areas in which Prof. Dowżenko took a keen interest were: 1) CSF and its poorly investigated properties, 2) syphilis of the nervous system - diag- 
nostics, therapy and prognosis, 3) epilepsy - therapy, epidemiology and social impact, 4) extrapyramidal system diseases.

Dowżenko's interest in CSF was first piqued during WWII, when he worked in the Warsaw's Neurology Department. Dowżenko's first publications which appeared in the 1940s demonstrate that he mastered laboratory techniques used for examining CSF very early on, and was thus able - on the basis of his own material - to contribute a lot of methodological findings and interpretative insights. He found that in some cases of multiple sclerosis the level of eosinophilia in CSF could be similar to that observed in parasitic conditions (1946). $\mathrm{He}$ also confirmed that eosinophils could appear in CSF after the administration of foreign serum. He described the mechanism underlying changes occurring in CSF proteins after incidental CSF contamination with blood, e.g. during lumbar puncture (1946). He explained the phenomenon of "paralytic curve" of colloidal gold reaction in CSF in subarachnoid hemorrhages (discovering the role of hemoglobin experimentally). In collaboration with Hausmanowa, he published reports on meningeal irritation after intrathecal administration of penicillin. He was the first to draw attention to the usefulness of Weichbrodt's reaction in the differentiation of massive fluid shifts developing in Guillain-Barré syndrome or resulting from congestion. All the works were original papers demonstrating Dowżenko's thorough expertise in laboratory studies. It should also be noted that Prof. Dowżenko deve loped and put into clinical use a water manometer used for measuring CSF pressure during lumbar puncture. A full account of CSF was presented by Prof. Dowżenko in his part of a neurology handbook in 1951 and, more extensively, in a monograph entitled Badania i diagnostyka plynu mózgowo-rdzeniowego [Studies and diagnostics of cerebrospinal fluid] in 1950.

Another area in which Professor Dowżenko was ardently interested was syphilis of the nervous system a major and complicated diagnostic and therapeutic problem in the early post-war years. Dowżenko undertook clinical studies into various neurological forms of the disease, cooperating with J. Towpik from the Institute of Venereology. In a range of works based on own material, the two authors established foundations for the diagnostics of CNS syphilis, with a special focus on active infection. Professor's extensive knowledge of CSF studies proved extremely useful for that research. The conclusive proof of disease activity was found to be CSF pleocytosis. Gradually disappearing pleocytosis proves the efficacy of treatment and vice versa - gradually increasing pleocytosis suggests a relapse of the disease, i.e. ineffective treatment. Specific protein changes are of lesser importance here. The findings gave rise to different therapeutic guidelines. Authors of the studies verified the efficacy of penicillin treatment and a range of combined therapeutic methods. Dowżenko's first work on various antibiotics in the therapy of CNS syphilis published in Poland came out in 1952. The first monograph on that topic, authored by two cooperating professors, appeared in 1954. The monograph describes indications which became a basis for therapies subsequently used in syphilology. In several reports published in later years Professor Dowżenko and his associates analyzed reasons for failed treatment in isolated cases. The last major work authored by the Professor in this field contained a compilation of cases of CNS syphilis treated at neurology departments in Poland in 1956-1965. Among many interesting conclusions, the author stated that the incidental (and already widespread) use of antibiotics probably had an inhibitory effect on the development of syphilitic changes in the CNS.

The third area absorbing Professor Dowżenko's interest from mid-1950s was epilepsy. Aware of the medical and social importance of problems associated with various forms of epilepsy, while still working in Poznań he initiated the establishment of Wielkopolska Committee for Epilepsy in 1957. Members of the organization included neurologists and neurosurgeons who were interested in the pathogenesis, diagnostics and treatment options for epileptic seizures. In the course of time, the group grew into the Committee for Epilepsy of the Polish Neurological Society (PNS) and ultimately transformed into a general Polish section of the PNS. The next initiative undertaken by the Professor was founding a Polish branch of the International League Against Epilepsy, an unprecedented venture in Eastern Bloc countries. From the very onset of their activity, the two organizations dealt not only with medical, but also social and economic aspects relating to epilepsy. Large-profile trials were conducted and their results were presented during joint sessions held by the Committee of Neurological Sciences of the Polish Academy of Sciences (PAN) and PNS sections (in 1971 Prof. Dowżenko was elected Head of the Committee for Studies into Epilepsy of PAN's Committee of Neurological Sciences). Topics discussed during the sessions varied to a great extent. They concerned, for example, antiepileptic drugs, medicolegal decisions, childhood epilepsy, effects of antiepileptic drugs on learning and prevention of epileptic seizures. Prof. Dowżenko believed that activities pursued by the groups investigating various epilepsy-related problems were very beneficial both from 
the viewpoint of science and teaching. He valued greatly medical and social contributions achieved during the sessions, especially in view of the fact that they resulted in a steady increase of publications promoting knowledge of ways to help patients. One of Dowżenko's associates prepared a compilation of publications related to epilepsy which appeared in Poland, demonstrating their tenfold increase between 1951 and 1974. After Prof. Dowzen ko took over as Head of the Neurology Department in Pruszków, epilepsy became one of the main areas of research conducted at the Department and remained so until his death. Studies focused on a wide array of aspects including diagnostics, clinics, therapy, psychology, neuroradiology and electrophysiology. Also, it was the Professor's initiative to begin investigations into the epidemiology and social issues involved in epilepsy, later continued within the framework of Polish-American scientific collaboration. The studies allowed an objective assessment of patient prognosis in epilepsy which proved more favorable than previously thought. A range of pioneering works were also published about causes of mortality, employment problems, disability and social attitudes of different groups towards epileptic patients.

In addition to epilepsy, during its final period of operation the Department specialized mainly in extrapyramidal system diseases, various clinical and therapeutic aspects. For example, the first Polish use of levodopa in Parkinson's disease was in Pruszków in the second half of 1960s. A range of very important experiences with the drug were published, which helped promote the therapy, ground-breaking at the time, in Poland.

Overall, Professor Dowżenko's scientific activity in various areas of neurology was extraordinarily creative and full of innovative ideas.

He published over one hundred and ten works including 92 original papers, and 14 handbooks and monographs - Poland's first modern monograph about epilepsy among them. From 1958 until the end of his professional career Professor Dowżenko was the editorin-chief of the Neurologia i Neurochirurgia Polska [Polish Neurology and Neurosurgery] bimonthly, who made himself known for his remarkable conscientiousness and attention to scientific merit. He supervised around a dozen doctoral dissertations. Many members of his team later went on to become independent researchers (M. Wender, Z. Huber, M. Kozik, H. Powiertowski, W. Horyd, J. Zieliński, D. Wochnik, W. Cendrowski, S. Nowak).

Professor Dowżenko was an educator by heart. His handbooks, which were always of the highest academic quality, were used by the majority of neurologists prac- ticing in Poland today. In this sense, nearly all of us can see ourselves as his disciples - especially considering the fact that we experienced and still remember his wisdom, excellent attitude to patients, and his full responsibility and criticism in research work. The Professor was an incredibly diligent and demanding, and yet modest, delicate and warm person.

\section{Selected handbooks and monographs:}

1. Dowżenko A. Płyn mózgowo-rdzeniowy. PZWL, Warsaw 1950.

2. Dowżenko A., Jakimowicz W. Choroby układu nerwowego. Podręcznik dla studentów medycyny. PZWL, Warsaw 1951 (and 4 subsequent editions until 1966).

3. Dowżenko A. Zapalenie opon mózgu i rdzenia. PZWL, Warsaw 1952.

4. Dowżenko A., Towpik J. Kiła układu nerwowego. PZWL, Warsaw 1954.

5. Dowżenko A. Choroby układu pozapiramidowego. PZWL, Warsaw 1958.

6. Dowżenko A. (ed. and co-author). Padaczka. PZWL, Warsaw 1971.

7. Dowżenko A. (ed. and co-author). Neurologia kliniczna. PZWL, Warsaw 1974. 